\title{
Yellow fever vaccine and risk of developing serious adverse events: a systematic review
}

\author{
Ruben Porudominsky ${ }^{1}$ and Eduardo H. Gotuzzo ${ }^{1}$
}

Suggested citation Porudominsky R, Gotuzzo EH. Yellow fever vaccine and risk of developing serious adverse events: a systematic review. Rev Panam Salud Publica. 2018;42:e75. https://doi.org/10.26633/RPSP.2018.75

ABSTRACT Objective. To evaluate contraindications and precautions for the yellow fever vaccine (YFV) in risk populations.

Methods. A literature review was conducted by searching PubMed for "yellow fever vaccine" and "adverse events" (AEs); 207 studies were found, and 43 of them met the inclusion criteria and were included in a systematic review.

Results. The results for first dose of YFV in elderly patients were conflicting-some showed AEs while some showed benefits. Therefore, precaution and case-by-case decisionmaking for YFV in this population are advised. The same precautions are warranted for YFV in infants 6-8 months, with the vaccine contraindicated in those $<6$ months old and safe after 9 months of age. YFV seems safe in the first trimester of pregnancy, and probably throughout gestation, as it was not associated with increased malformations. During breastfeeding, YFV continues to be controversial. The vaccine seems safe in people being treated with immunomodulatory or immunosuppressive therapy, people with immunosuppressive diseases, and solid organ and hematopoietic stem cell transplant patients; in stem cell transplants, however, a booster dose should only be applied once immunity is recovered. $H I V$-infected patients with a CD4+ count $>200 \mathrm{cells} / \mathrm{mm}^{3}$ do not have increased risk of AEs from YFV. Egg allergy vaccination protocols seem to provide a safe way to immunize these patients.

Conclusions. YFV safety has been confirmed based on data from many vaccination campaigns and multiple studies. AEs seem more frequent after a first-time dose, mainly in risk groups, but this review evaluated YFV in several of the same risk groups and the vaccine was found to be safe in most of them.

Keywords Yellow fever; yellow fever vaccine; drug-related side effects and adverse reactions; risk groups; systematic review.

Yellow fever (YF) is a viral hemorrhagic infection from the Flaviviridae family, transmitted by Aedes aegypti mosquitoes (1). The disease is found in

\footnotetext{
Universidad Peruana Cayetano Heredia, Lima, Peru. Send correspondence to: Eduardo $\mathrm{H}$. Gotuzzo, eduardo.gotuzzo@upch.pe
}

47 countries worldwide, 34 in Africa and 13 in Central America and South America, with an annual estimated incidence of 200000 cases, a burden of 84000 170000 severe patients, and 29000 60000 deaths in 2013 (2). Due to the lack of antiviral therapy, the infection is prevented by the live attenuated viral YF vaccine (YFV) of the 17D lineage (1).
Despite the relative safety of the YFV, since 1996, adverse events (AEs) and serious adverse events (SAEs) reports have emerged, including yellow fever vaccineassociated neurological disease (YELAND), yellow fever vaccine-associated viscerotropic disease (YEL-AVD), and egg allergy-associated hypersensitivity reactions, namely anaphylaxis. YEL-AND, 
formerly known as post-vaccinal encephalitis, was the most common SAE, with 23 reported cases (including 16 infants $<9$ months old) from 1945 to 2007. YELAVD, initially called febrile multi-organic failure syndrome, was reported in 10 travelers worldwide from 1996 to 2001. Beginning in 2002, the reports have increased, with two suspected cases of YEL-AND and four cases of YEL-AVD in the United States that year (3). This trend continues to grow, and even old reports suggest that AEs may have been occurring since the introduction of the vaccine in 1945 (4).

While the estimated risk of complications in vaccinated patients is low in U.S. and European travelers, with the rate of YEL-AVD ranging from 0.25 to 0.4 per 100000 doses, in a vaccination campaign in Peru, the rate of YEL-AVD was 7.9 per 100000 doses (5). In a study of preventive vaccination in eight African countries, the rate of YEL-AVD, YEL-AND, and anaphylaxis was 0.25 to $0.4,0.25$ to 9.9 , and 0.9 to 1.8 cases per 100000 doses respectively (6). In an observational prospective study of 700 vaccinated travelers older than 60 years in Brazil, for the years 2009 to 2010, AEs were considerably higher in first-dose vaccinated patients $(17.5 \%)$ compared to those who had a previous dose $(9.5 \%)$, but there were no reported SAEs; the mean time to onset of symptoms was 4.2 days (0-15 days) and the mean duration of symptoms was 2.7 days (0.5-10 days) (7).

Based on the rate of reported AEs and SAEs, YFV contraindications (Table 1) and precautions (Table 2) were issued by the World Health Organization (WHO) (8).

In June $2016 \mathrm{WHO}$ withdrew its recommendation for a booster dose of YFV every 10 years due to the optimal levels of immunogenicity and lifelong protection shown from a single dose, based on various research, including a 2013 Peruvian systematic review of 22 studies on the protective efficacy and duration of immunity of YFVs (9). Nonetheless, the booster requirement remains for certain populations, such as pregnant patients, stem cell transplant recipients, and HIV-infected patients (10).

The benefits of the YFV have been shown in recent outbreaks. For example, last February 2017, a YF outbreak that began in 2015 in Angola and the Democratic Republic of Congo, with 7293 suspected cases and 137 confirmed deaths, officially ended after a crucial vaccination campaign, which depleted the global stockpile of YFV several times (11). Another YF outbreak that began in Brazil in 2017 and is still ongoing shows the need for the YFV to control epidemics, with 398 confirmed cases and 143 deaths as of April 2017, mostly in rural areas (12).

Therefore, the importance of massive YFV vaccination campaigns is clear, but the risk of AEs remains, especially for those in high-risk groups inadvertently exposed to the vaccine. This systematic review evaluated contraindications and precautions for the YFV in risk populations.

\section{MATERIALS AND METHODS}

A literature review of AEs occurring after YFV in high-risk groups was conducted by searching the public database PubMed for the words "yellow fever," "vaccine," "adverse events," and "contraindication" as well as the following $\mathrm{MeSH}$ terms: "yellow fever vaccine/ adverse effects" and "yellow fever vaccine/contraindications."

A total of 207 papers were found which, after filters and review, were narrowed down to 43 included studies. The process is depicted in Figure 1. The methodologies used in the included studies are listed in Table 3 and the number of studies covering each population group at risk of developing AEs is shown in Table 4.

TABLE 1. Contraindications for the yellow fever vaccine (YFV) according to World Health Organization recommendations

\begin{tabular}{l}
\hline YFV contraindication \\
\hline Age $<6$ months \\
Thymus disease \\
Immunomodulatory or immunosuppressive therapy \\
Symptomatic HIV infection or CD $4+<200 / \mathrm{mm}^{3}$ \\
Malignant neoplasm \\
Transplant patient \\
Primary immunodeficiencies \\
Hypersensitivity to egg antigens \\
Source: Prepared by the authors based on data from (8).
\end{tabular}

TABLE 2. Population groups at risk of developing adverse events (AEs) after yellow fever vaccine (YFV) and thus requiring precautions and case-by-case analysis for inclusion in YFV campaigns according to World Health Organization recommendations

\begin{tabular}{l}
\hline Population groups at risk of AEs after YFV \\
\hline Infants $6-8$ months old (YFV only recommended for \\
this group during epidemics when risk of \\
transmission may be very high) \\
Adults $>60$ years at first vaccination \\
Pregnant women \\
Breastfeeding women
\end{tabular}

Source: Prepared by the authors based on data from (8).

FIGURE 1. Flowchart of study selection process for systematic review of yellow fever vaccine (YFV) and risk of developing serious adverse events, Peru, 2017

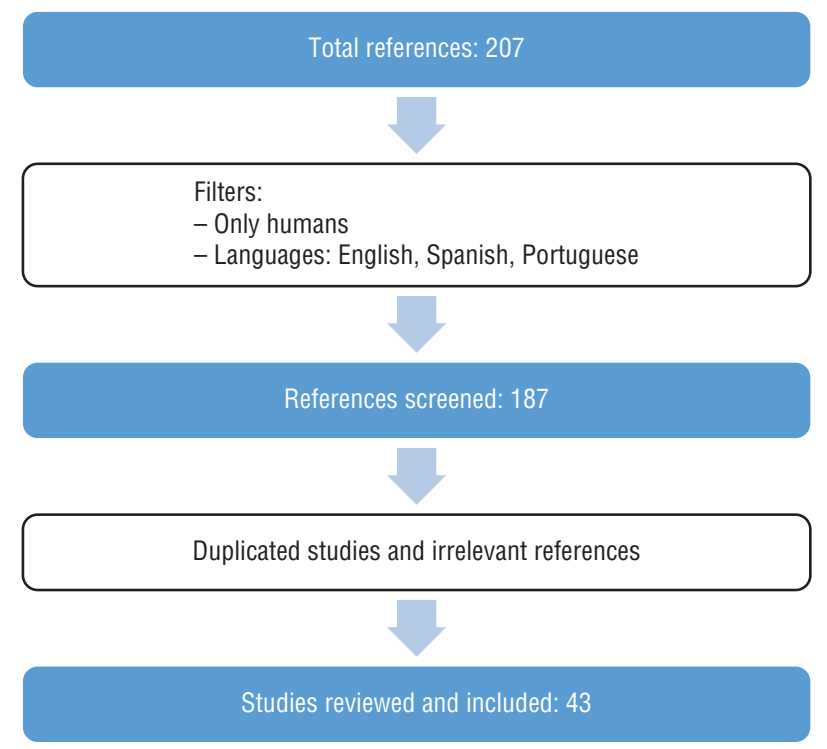

Source: Prepared by the authors based on the study selection process. 
TABLE 3. Methodology of studies included in a systematic review of yellow fever vaccine (YFV) and risk of developing serious adverse events $(n=43)$, Peru, 2017

\begin{tabular}{lc}
\hline Methodology & No. of studies \\
\hline Case reports & 11 \\
Case series & 6 \\
Prospective cohort & 8 \\
Retrospective cohort & 8 \\
Case controls & 1 \\
Randomized controlled trial & 2 \\
Review article & 7 \\
Total & 43 \\
\hline
\end{tabular}

Source: Prepared by the authors based on the systematic review.

TABLE 4. Number of studies, by study sample at risk of developing adverse events (AEs) from yellow fever vaccine (YFV), included in systematic review of YFV and risk of AEs $(n=43)$, Peru, 2017

\begin{tabular}{lc}
\hline Study sample & No. of studies \\
\hline Elderly & 8 \\
Infants and young children & 5 \\
Pregnant women & 4 \\
Breastfeeding women & 3 \\
People with thymus disease & 1 \\
People receiving immunomodulatory or immunosuppressive therapy & 6 \\
People with HIV infection & 8 \\
Transplant patients & \\
- Solid organ & 2 \\
- Hematopoietic stem cell & 3 \\
People with multiple sclerosis & 1 \\
People with hypersensitivity to egg antigens & 2 \\
\hline
\end{tabular}

Source: Prepared by the authors based on the systematic review.

\section{RESULTS}

\section{Elderly}

Many studies have identified patients older than 65 years-mainly those receiving their first dose of the vaccine-as being at risk for SAEs. For example, a 2001 report from the U.S. Vaccine Adverse Event Reporting System (VAERS) showed an SAE reporting rate for 19901998 of 5.8 and 18.1 per 100000 doses for people $65-74$ years old and $\geq 75$ years old respectively (13). The revised reporting rate from the 2015 VAERS report update for patients older than 60 years was 5.3 per 100000 vaccinations, with a risk of YEL-AVD and YEL-AND of 1.8 and 1.4 per 100000 vaccinations respectively (14). In a review from Australia's Adverse Drug Reactions Advisory Committee for the years 1993-2002, the reporting rate for SAEs in people more than 65 years old was higher than the younger group's rate (relative risk reduction
(RRR): 8.95 ; 95\% confidence interval (CI): 1.49-53) (15).

However, recent studies on AEs and SAEs associated with YFV not only failed to show any SAEs but also indicated no differences in the rate of AEs between the regular population and elderly groups. The abovementioned study of 700 vaccinated travelers older than 60 years in Brazil showed similar rates of AEs for the two groups: 15.3\% for the elderly and $17.7 \%-21.7 \%$ for the general population, despite the presence of concomitant diseases in $60.3 \%$ of the patients studied; most immunosuppressed people were not vaccinated $(3.9 \%)$, and the few who were did not develop AEs (7). In the large study of preventative vaccination in eight African countries, only two cases of hypersensitivity were reported in the elderly, and, again, no SAEs were found (6).

In a 2013 systematic review of YELAVD risk in elderly patients, 529 articles were reviewed and 33 included (16).
Despite the higher prevalence and increased risk of SAEs in patients older than 60 years compared to younger patients, the evidence was poor, and limited; therefore, the authors conclude that vaccination with YFV should be determined case by case (16).

New studies show a higher rate of AEs in younger patients compared to their older counterparts, and the absence of SAE reports. In a 2011 prospective controlled cohort study of 60 patients, AEs (all mild) were more frequent in younger patients than in elderly patients (30\% versus $14 \%$ for injection site-related (local) AEs and $40 \%$ versus $21 \%$ for systemic AEslow-grade fever, myalgia, asthenia, or headache) (17). In a 2016 prospective observational study in Tokyo with 666 patients, $55.6 \%$ reported mild AEs lasting less than 5 days-34.5\% local and $38.7 \%$ systemic - and most of the cases were reported in the younger population (60.3\% versus $42.9 \%$; $P<0.001)$ (18).

\section{Infants and young children}

The WHO and U.S. Centers for Disease Control and Prevention (CDC) contraindication for the YFV in infants is for those younger than 6 months, with precautions for children up to 9 months and everyone older than 9 months who lives in or travels to endemic areas (8, 10). These indications are based on 16 infant cases among the 23 initial reported cases of YEL-AND; the other 7 cases were persons aged 3 to 76 years, including one fatal case of encephalitis in a 3-year-old (19). YEL-AND is the main SAE for the YFV.

Two randomized clinical trials indicate the safety of YFV in infants older than 9 months. The first one compared two different YFV 17D vaccines in 1107 children in Peru, where $60 \%$ had at least one mild and self-limited $\mathrm{AE}$, but there were no reported SAEs (20). In the second study, in Brazil, 1966 children up to 23 months old received either the 17DD or 17DD$213 / 77$ substrains of the 17D vaccine and showed similar, mild local or systemic symptoms $(25 \%)$, with only two SAEs that had no causal association (21). Another study showed six cases in children 3 to 5 years old (two with YEL-AND and one with YEL-AVD, who died, and three cases of hypersensitivity), but the incidence rates were very low (6). 


\section{Pregnancy}

YFV safety in pregnancy is not well established and fetus infection and malformations are dreaded AEs. Available studies are based on massive vaccination campaigns where pregnant women were inadvertently vaccinated.

The first case of mother-to-child transmission was reported in 1993 in Trinidad, where 1 in 41 infants whose mothers were accidentally immunized was diagnosed with asymptomatic congenital YF infection (22). A similar study in Brazil, of 39 inadvertently exposed pregnant patients and 74 controls, reported an increase in spontaneous abortions associated with YFV (23).

Nonetheless, recent studies show different results. A 2000 campaign in Brazil demonstrated first-trimester safety for the 17DD vaccine, and maternal seroconversion after a year, in 480 unintentionally vaccinated pregnant women (mean gestational age: 5.7 weeks) (24). A study of another vaccination campaign in Brazil with unintentional exposure to 304 infants (mean gestational age: 5.3 weeks) showed no increased risk of major malformations, and a false association with minor dimorphisms (25).

\section{Breastfeeding}

Despite the theoretical risk of YFV secretion through breast milk, associated with an adjacent pathology, up until 2009 there were no reported cases. In April 2009 , the first confirmed case of YF transmission through breast milk was reported in Brazil: an infant whose mother had received the YFV 8 days before the onset of symptoms developed meningoencephalitis, confirmed with viral ribonucleic acid (RNA) (obtained from cerebrospinal fluid) identical to the YF RNA in the 17DD vaccine; maternal blood and milk were not sampled (26).

Since then, two more unconfirmed cases have been reported: a 38-day-old infant in Brazil with a fever that evolved into a convulsive crisis was diagnosed with meningoencephalitis through a cerebrospinal fluid sample, without viral confirmation (27), and a Canadian infant whose mother was vaccinated when the newborn was 10 days old developed convulsions at 5 weeks of life (28). Again, as stated above for YFV effects in infants and young children, YEL-AND is the most important SAE in this population.

\section{Thymus disease}

Thymus disorder is a contraindication for YF vaccination due to the history of thymus tumor or myasthenia gravis (MG) and thymectomy in four (16\%) of the initial 25 cases of YEL-AVD identified up until October 2004 (19).

\section{Immunomodulatory or immunosuppressive therapy}

Taking immunosuppressive drugs and having immunosuppressive diseases are considered a contraindication to YFV, but the term is broad and many studies show the safety of the vaccine in different settings. Details of some of the studies with AEs reports are mentioned below.

A total of 70 rheumatologic patients were vaccinated with the 17DD vaccine; the specific patient diseases were rheumatoid arthritis (RA) and systemic lupus erythematous, among others; the medications used were methotrexate, glucocorticoids, sulfasalazine, leflunomide, cyclophosphamide, or biologic drugs (such as infliximab) (29). Only 16 of these immunosuppressed patients developed AEs, which were all minor (e.g., just one mild event), resulting in a reported rate of AEs very similar to the rate found for immunocompetent patients $(22.5 \%$ versus $<25 \%$ respectively) (29).

In a prospective study of 24 vaccination sites conducted in France from 2008 to 2011, 34 travelers on systemic glucocorticoid therapy for RA and upper respiratory tract infections (URTIs) and 68 healthy controls paired by age and vaccination history were immunized with the 17D vaccine; the mean duration of therapy was 10 months, with a mean dose of $7 \mathrm{mg} /$ day (30). The RA/URTI patients had a higher rate of moderate/severe local reactions to the vaccine versus the controls (12\% versus $2 \%$ respectively), and no SAEs were reported (30).

Other research on the YFV with no reported AEs validates the safety of the vaccine in potential risk groups, including an observational study of 17 RA patients (13 women and 4 men) aged 26-58 years, treated with infliximab and methotrexate (31), and a study in 15 Dutch travelers with RA, psoriatic arthritis, psoriasis, scleroderma, and pyoderma gangrenosum, treated with methotrexate, etanercept, leflunomide, or prednisolone (32).
Two case reports, without AEs, were also included in the review: one for a 27-year-old male with psoriatic arthritis treated with methotrexate, and one for a 63-year-old female with Crohn's disease treated with adalimumab $(33,34)$.

Several conclusions can be drawn from the review of these studies: first, vaccination of groups treated with immunosuppressive therapy-glucocorticoids, methotrexate, azathioprine, leflunomide, cyclophosphamide, and biologic tumor necrosis factor (TNF)-alpha drugs such as infliximab and adalimumab-seems safe, including glucocorticoid treatment in doses higher than $5 \mathrm{mg} /$ day. Severe local reactions were rare, and other than in a few studies, there was no increased risk of SAEs. Therefore, diseases such as RA (the most common illness in the study samples, followed by psoriatic arthritis, spondyloarthropathy, and systemic lupus erythematous, among others) did not seem to play a role in the occurrence of AEs.

\section{HIV immunosuppression}

The safety of the YFV in HIV patients with a CD4+ cell count $>500$ cells $/ \mathrm{mm}^{3}$ was confirmed many years ago. The first case report was from the Institut Pasteur (Paris), in 1995, where 44 HIV+ patients with CD4+> $200 \mathrm{cell} / \mathrm{mm}^{3}$ vaccinated with the YFV achieved immunogenic effectiveness without AEs (35). Another two case reports showed the safety of YFV in patients with a CD4+ > $500 / \mathrm{mm}^{3}$ (36).

Many other studies have demonstrated the safety of YFV in patients with a CD4+ count $>200 / \mathrm{mm}^{3}$ based on the lack of SAEs. One study covered a Swiss cohort of 102 HIV-infected patients (mean age 34.7 years, 53\% male) with a mean CD4+ of $537 \mathrm{cell} / \mathrm{mm}^{3}$ (ranging from 11 to 1730 cells $/ \mathrm{mm}^{3}$ ), where 44 patients had a CD4+ > 500, 22 had CD4+ $350-499,13$ had a count of 200-349, 7 had a count less than $200 / \mathrm{mm}^{3}$, and $83 \%$ of them were vaccinated for the first time (37). The second was a retrospective study of $12 \mathrm{HIV}$-infected patients who received the $17 \mathrm{D}$ vaccine and had a CD4+ of $561 \pm 363$ cells $/ \mathrm{mm}^{3}$, where only one patient presented transitory fever and pharyngitis (38).

Another retrospective study evaluated immunogenicity and tolerability in 23 French HIV patients, 56\% men, with a mean age of 41 years (ranging from 12-55 
years, with only one 12-year-old minor), and a mean CD4+ of 549 cells $/ \mathrm{mm}^{3}$, with only one patient with CD4+ $<200$ cells. Mild AEs were described in four patients, but there were no SAEs (39).

In an important Cochrane review of three cohort studies, including the ones mentioned above, where the quality of the studies was described as "low" to "very low," and the small sample size limited the conclusions that could be drawn, the YFV was found to be potentially safe in HIV-infected patients, as none of the studies reported SAEs (40).

In a 2008 cross-sectional study of 114 HIV-vaccinated adults from Brazil in which seven adult patients received the YFV, and two had a CD4 $+<200$ cells/ $\mathrm{mm}^{3}$, with no reported AEs, the YFV was shown to be safe even with a low CD4+ count (41).

One study reported mortality in a 53-year-old male HIV patient with a CD4+ count of 108 cells $/ \mathrm{mm}^{3}$ who presented myeloencephalitis after vaccination and died (42).

HIV prevalence is high in many countries where $\mathrm{YF}$ is endemic, and there is an increase in HIV-infected people traveling to endemic countries. Various studies have shown that the YFV is safe in HIV patients with a low viral load and a CD4+ count $>200$ cells $/ \mathrm{mm}^{3}$ and might even be safe in patients with $<200$ cells $/ \mathrm{mm}^{3}$.

\section{Transplant}

Although transplant is found as a contraindication for the YFV in CDC guidelines, many studies show that the YFV can be safe post-transplant. The YFV vaccine should be deferred in patients with a medical history of transplant until their immune system recovers.

Solid organ. No AEs or SAEs were reported in 19 patients (11 men and 8 women, mean age $45.6 \pm 13.6$ years) with a solid organ transplant (14 kidney, 3 heart, and 2 liver) who received the YFV while on immunosuppressive therapy with various drugs (azathioprine, cyclosporine, deflazacort, mycophenolate, prednisone, sirolimus, and tacrolimus) (43).

In addition, a 55-year-old who underwent a renal transplant 19 years before vaccination, received cyclosporin and mycophenolic acid, and was prophylactically treated with intravenous immunoglobulin, did not present SAEs (44).
Hematopoietic stem cell. Data on the safety and immunogenicity of live virus vaccines in hematopoietic stem cell transplant patients are limited, and the information available is based on case reports.

One of the first case reports was for a male patient with myeloma immunoglobulin G (IgG) lambda (in 1998) who received chemotherapy (with vincristine, adriamycin, and daunorubicin, followed by melphalan), and, later, a human leukocyte antigen (HLA)-compatible transplant (in 1999), going into remission. In 2002, after two years without immunosuppressive therapy, he received the YFV without AEs and had a good response (45).

The second case report, and the first for a patient older than 60 years, was for a 62-year-old patient who had an allogeneic bone marrow transplant due to chronic myelogenous leukemia nine years before his uneventful immunization with YFV (in 2005), and was being treated at the time with glucosamine and inhaled fluticasone (46).

The third case report was for a 39-yearold male patient with a history of ablative suppression of stem cell in acute myelogenous leukemia who initiated chemotherapy seven days after the YFV (in 2011). There was no AE and the viremia diminished after some time (47).

\section{Multiple sclerosis}

A small study showed an increase in the exacerbation of multiple sclerosis in seven patients who received the 17D substrain 17D-204, with a risk of 8.57 compared to 0.67 in the period before the vaccination (48). However, this could be associated with other factors of the disease, so conclusions cannot be drawn.

\section{Hypersensitivity to egg antigens}

Egg allergy affected up to $2.5 \%$ of children and $0.1 \%$ of adults in European and American studies, and $5 \%$ to $30 \%$ in South America (49). Therefore, the amount of ovalbumin in YFV is a theoretical concern in patients with egg allergy that require the vaccine.

One study measured the content of ovalbumin in the U.S. YFV, which was higher than the safest approved value in vaccinated patients with an egg allergy (50). However, three studies evaluated successful desensitization processes in eight patients with egg allergy, without AEs (49).

Interestingly, a protective response was found in a Dutch study, with $0.1 \mathrm{ml}$ of intradermic YFV (20\% of the dose) in egg allergy patients causing only local wheals and no AEs (51).

\section{DISCUSSION}

YEL-AND can be seen as the most important SAE in infants (including during breastfeeding) and in the elderly. However, in other risk groups, few SAEs were reported, so conclusions about the most common SAEs cannot be drawn. Although some studies referred to cases with certain types of SAEs, they were not associated with the risk factors reviewed here.

\section{Causality}

When looking for causes of AEs, identification of different factors is sought. Globally, YFV AEs have not been related to a specific vaccine lot, with the exception of the abovementioned Peruvian vaccination campaign, in Ica, where five cases occurred with the same YFV lot (5).

Another factor could be the dose used in the vaccines. In a randomized, double-blinded, clinical trial, in which different doses of the vaccine were used, only one minor AE (local pain) was reported, and it was significantly correlated with a higher dose (52). In two Brazilian studies (in 1999 and 2009) in which 17DD vaccines erroneously given in higher doses (25 times and 10 times the normal dose respectively) were injected in a total of 63 patients (14 and 49 respectively), mostly adults, of both sexes, did not report an increase in major AEs; only one suspected YEL-AVD case occurred (in a 6-year-old girl, who had spontaneous resolution) $(53,54)$.

\section{Study limitations}

Notwithstanding the evidence found in this systematic review, firm conclusions about YFV risk, AEs, or SAEs cannot be drawn due to the observational methodology of the included studies and the lack of power of one of the clinical trials.

\section{New risk factors}

A previous review of research on YFV, AEs, and SAEs showed increased incidence in YEL-AVD cases and death in 
women aged 19 to 34 years (55). An analysis from the U.S. VAERS also revealed that AEs were more common in women (61\%) (56). However, the data are still preliminary and require evaluation of the cofactors and causalities.

Another possible risk might be associated with genetic alterations, as seen with another virus from the Flaviviridae family, the West Nile virus (3). A fatal case report on YEL-AVD in a 64-year-old male patient in the United States identified chemokines receptor CCR5 and its ligand RANTES (regulated on activation normal $\mathrm{T}$ cell expressed and secreted) polymorphism. Further studies might clarify its relevance (57).

\section{Future directions: new diagnostic methods}

A common problem in many of the studies evaluated in this review was the lack of documentation for all patients in the study sample, especially those who participated in massive immunization campaigns. Lost patients, along with symptoms wrongly associated with other pathologies, mean the loss of AE reports, which are crucial for the development of a vaccine safety profile.

One study evaluated the use of telemedicine to report AEs through the "TeleWatch" program. The results were

1. Beck AS, Barrett AD. Current status and future prospects of yellow fever vaccines. Expert Rev Vaccines. 2015;14(11):1479-92. doi: 10.1586/14760584.2015.1083430.

2. World Health Organization. Yellow fever fact sheet [Internet]. Geneva: WHO; 2016 [updated March 2018]. Available from: http: / / www.who.int / mediacentre / factsheets/fs100/en/ Accessed on 3 April 2018.

3. Barnett ED. Yellow fever: epidemiology and prevention. Clin Infect Dis. 2007;44(6):850-6. doi: 10.1086/511869.

4. Engel AR, Vasconcelos PF, McArthur MA, Barrett AD. Characterization of a viscerotropic yellow fever vaccine variant from a patient in Brazil. Vaccine. 2006;24(15):28039. doi: 10.1016/j.vaccine.2006.01.009.

5. Whittembury A, Ramirez G, Hernández H, Ropero AM, Waterman S, Ticona M, et al. Viscerotropic disease following yellow fever vaccination in Peru. Vaccine. 2009;27(43):5974-81. doi: 10.1016/j.vaccine. 2009.07.082

6. Breugelmans JG, Lewis RF, Agbenu E, Veit O, Jackson D, Domingo C, et al. Adverse events following yellow fever preventive vaccination campaigns in eight African encouraging, with symptoms reports suggesting AEs. Despite the lack of a control group, the study shows a new direction in the report of complications (58).

\section{Conclusions}

YFV safety has been confirmed in many studies, and the millions of vaccines that have been disseminated worldwide, without AEs, are proof of that. When AEs are seen, they are usually the result of a first-time dose rather than a booster, and occur mainly in risk groups.

In this review, several population groups at risk of developing AEs were evaluated, and the YFV was safe in most of them. Data for the first dose in the elderly were conflicting-some showing AEs and some showing benefits-so precaution and case-by-case decision-making on the use of YFV in this population group are advised. The same precautions are warranted in infants 6-9 months old, and the vaccine is contraindicated in children less than 6 months old. In pregnancy studies, the vaccine seems safe in the first trimester, and probably throughout gestation, as it is not associated with increased malformations, as opposed to YFV during breastfeeding, which continues to be controversial.

YFV seems safe in those with various immunosuppressive diseases and/

\section{REFERENCES}

countries from 2007 to 2010. Vaccine. 2013;31(14):1819-29. doi: 10.1016/j.vaccine. 2013.01.054.

7. Miyaji KT, Luiz AM, Lara AN, do Socorro Souza Chaves T, Piorelli R de O, Lopes $\mathrm{MH}$, et al. Active assessment of adverse events following yellow fever vaccination of persons aged 60 years and more. Hum Vaccin Immunother. 2013;9(2):277-82. doi: $10.4161 /$ hv.22714.

8. World Health Organization. Vaccines and vaccination against yellow fever: WHO Position Paper, June 2013recommendations. Vaccine. 2014;33(1): 76-7. doi: 10.1016/j.vaccine.2014.05.040.

9. Gotuzzo E, Yactayo S, Córdova E. Efficacy and duration of immunity after yellow fever vaccination: systematic review on the need for a booster every 10 years. Am J Trop Med Hyg. 2013;89(3):434-44. doi: 10.4269/ajtmh.13-0264.

10. Staples JE, Bocchini JA Jr, Rubin L, Fischer M; Centers for Disease Control and Prevention (CDC). Yellow fever vaccine booster doses: recommendations of the Advisory Committee on Immunization Practices, 2015. MMWR Morb Mortal Wkly Rep. 2015;64(23):647-50. PMID: 26086636. or taking immunomodulatory or immunosuppressive therapies, as well as in solid organ and hematopoietic stem cell transplants, although in stem cell transplants a booster dose should only be applied after immunity is recovered. HIV-infected patients with a CD4+ count higher than 200 cells $/ \mathrm{mm}^{3}$ do not have an increased risk of AEs, and some studies show YFV might be safe even with lower immunity. Vaccination protocols for those with hypersensitivity to egg antigens seem to provide a safe way to immunize these patients.

Most AE reports related to YFV in highrisk populations come from small groups of exposed patients (usually inadvertently exposed patients), and these small samples, added to underreporting and the low quality of the studies included in this systematic review, limited the analysis of AEs and SAEs. Therefore, case-bycase decision-making should be used to determine if the benefit of YF vaccination in high-risk patients outweighs the risks.

\section{Conflicts of interest. None.}

Disclaimer. Authors hold sole responsibility for the views expressed in the manuscript, which may not necessarily reflect the opinion or policy of the RPSP/ $P A J P H$ or the Pan American Health Organization (PAHO).

11. World Health Organization. The yellow fever outbreak in Angola and Democratic Republic of the Congo ends [news release]. 14 Feb. WHO: Geneva; 2017. Available from: http://www.aho.afro.who.int/en/ news / 5941 / yellow-fever-outbreakangola-and-democratic-republic-congoends Accessed on 10 August 2017.

12. Secretaria de Estado de Saúde de Minas Gerais (BR). Informe epidemiológico da febre amarela [news release]. 12 Apr. Belo Horizonte: SES-MG; 2017. Available from: http: / / www.saude.mg.gov.br/component/gmg/story/9282-informeepidemiologico-da-febre-amarela-12-04

13. Martin M, Weld LH, Tsai TF, Mootrey GT, Chen RT, Niu M, et al. Advanced age a risk factor for illness temporally associated with yellow fever vaccination. Emerg Infect Dis. 2001;7(6):945-51. doi: 10.3201/ eid0706.010605.

14. Khromava AY, Eidex RB, Weld LH, Kohl KS, Bradshaw RD, Chen RT, et al. Yellow fever vaccine: an updated assessment of advanced age as a risk factor for serious adverse events. Vaccine. 2005;23(25): 3256-63. doi: 10.1016/j.vaccine.2005. 01.089 . 
15. Lawrence GL, Burgess MA, Kass RB. Agerelated risk of adverse events following yellow fever vaccination in Australia. Commun Dis Intell Q Rep. 2004;28(2):2448. PMID: 15460963.

16. Rafferty E, Duclos P, Yactayo S, Schuster M. Risk of yellow fever vaccine-associated viscerotropic disease among the elderly: a systematic review. Vaccine. 2013;31(49): 5798-805. doi: 10.1016/j.vaccine.2013.09.030.

17. Roukens AH, Soonawala D, Joosten SA, de Visser AW, Jiang $X$, Dirksen $K$, et al. Elderly subjects have a delayed antibody response and prolonged viraemia following yellow fever vaccination: a prospective controlled cohort study. PLoS One. 2011;6(12):e27753. doi: 10.1371/journal. pone. 0027753 .

18. Tanizaki R, Ujiie M, Hori N, Kanagawa S, Kutsuna S, Takeshita N. Comparative study of adverse events after yellow fever vaccination between elderly and nonelderly travellers: questionnaire survey in Japan over a 1-year period. J Travel Med. 2016;23(3):1-6. doi: 10.1093/jtm/taw012.

19. Marfin AA, Eidex RSB, Kozarsky PE, Cetron MS. Yellow fever and Japanese encephalitis vaccines: indications and complications. Infect Dis Clin North Am. 2005; 19(1):151-68. doi: 10.1016/j.idc.2004.11.004.

20. Belmusto-Worn VE, Sanchez JL, McCarthy K, Nichols R, Bautista CT, Magill AJ, et al. Randomized, double-blind, phase III, pivotal field trial of the comparative immunogenicity, safety, and tolerability of two yellow fever 17D vaccines (Arilvax and YF-VAX) in healthy infants and children in Peru. Am J Trop Med Hyg. 2005;72(2): 189-97. PMID: 15741556.

21. Collaborative Group for Studies of Yellow Fever Vaccine. A randomised double-blind clinical trial of two yellow fever vaccines prepared with substrains 17DD and 17D213/77 in children nine-23 months old. Mem Inst Oswaldo Cruz. 2015;110(6): 771-80. doi: 10.1590/0074-02760150176.

22. Tsai TF, Paul R, Lynberg MC, Letson GW. Congenital yellow fever virus infection after immunization in pregnancy. J Infect Dis. 1993;168(6):1520-3. PMID: 8245539.

23. Nishioka Sde A, Nunes-Araújo FR, Pires WP, Silva FA, Costa HL. Yellow fever vaccination during pregnancy and spontaneous abortion: a case-control study. Trop Med Int Health. 1998;3(1):29-33. doi: 10.1046/j.1365-3156.1998.00164.x.

24. Suzano CES, Amaral E, Sato HK, Papaiordanou PM; Campinas Group on Yellow Fever Immunization during Pregnancy. The effects of yellow fever immunization (17DD) inadvertently used in early pregnancy during a mass campaign in Brazil. Vaccine. 2006;24(9):1421-6. doi: 10.1016/j.vaccine.2005.09.033.

25. Cavalcanti DP, Salomão MA, LopezCamelo J, Pessoto MA, Campinas Group on Yellow Fever Immunization during Pregnancy. Early exposure to yellow fever vaccine during pregnancy. Trop Med Int Health. 2007;12(7):833-7. doi: 10.1111/ j.1365-3156.2007.01851.x.

26. Centers for Disease Control and Prevention (CDC). Transmission of yellow fever vaccine virus through
breast-feeding-Brazil, 2009. MMWR Morb Mortal Wkly Rep. 2010;59(5):130-2. PMID: 20150888.

27. Traiber C, Coelho-Amaral P, Ritter VR, Winge A. Infant meningoencephalitis probably caused by yellow fever vaccine virus transmitted via breastmilk. J Pediatr (Rio J). 2011;87(3):269-72. doi:10.2223/ JPED.2067.

28. Kuhn S, Twele-Montecinos L, MacDonald J, Webster P, Law B. Case report: probable transmission of vaccine strain of yellow fever virus to an infant via breast milk. CMAJ. 2011;183(4):E243-5. doi: 10.1503/ cmaj.100619.

29. Mota LM, Oliveira AC, Lima RA, SantosNeto LL, Tauil PL. Vacinação contra febre amarela em pacientes com diagnósticos de doenças reumáticas, em uso de imunossupressores. Rev Soc Bras Med Trop. 2009;42(1):23-7. doi: 10.1590/S0037-86822 009000100006.

30. Kernéis $S$, Launay $O$, Ancelle $T$, Iordache L, Naneix-Laroche V, Méchaï F, et al. Safety and immunogenicity of yellow fever 17D vaccine in adults receiving systemic corticosteroid therapy: an observational cohort study. Arthritis Care Res (Hoboken). 2013;65(9):1522-8. doi: 10.1002/acr.22021.

31. Scheinberg M, Guedes-Barbosa LS, Mangueira C, Rosseto EA, Mota L, Oliveira AC, et al. Yellow fever revaccination during infliximab therapy. Arthritis Care Res (Hoboken). 2010;62(6):896-8. doi: 10.1002/acr.20045.

32. Wieten RW, Jonker EF, Pieren DK, Hodiamont CJ, van Thiel PP, van Gorp EC, et al. Comparison of the PRNT and an immune fluorescence assay in yellow fever vaccinees receiving immunosuppressive medication. Vaccine. 2016;34(10):1247-51. doi: 10.1016/j.vaccine.2016.01.037.

33. Nash ER, Brand M, Chalkias S. Yellow fever vaccination of a primary vaccinee during adalimumab therapy. J Travel Med. 2015;22(4):279-81. doi: 10.1111/jtm.12209.

34. Stuhec M. Yellow fever vaccine used in a psoriatic arthritis patient treated with methotrexate: a case report. Acta Dermatovenerol Alp Pannonica Adriat. 2014;23(3):63-4. doi: 10.15570/actaapa. 2014.15.

35. Ericsson CD. Selected abstracts from papers presented at the Fourth International Conference on Travel Medicine, Acapulco, Mexico, April 23-27, 1995. J Travel Med. 2(2): 145. doi: 10.1111/j.1708-8305.1995.tb00640.x.

36. Receveur MC, Thiébaut R, Vedy S, Malvy D, Mercié P, Bras ML. Yellow fever vaccination of human immunodeficiency virus-infected patients: report of 2 cases. Clin Infect Dis. 2000;31(3):E7-8. doi: $10.1086 / 314031$.

37. Veit O, Niedrig M, Chapuis-Taillard C, Cavassini M, Mossdorf E, Schmid P, et al. Immunogenicity and safety of yellow fever vaccination for $102 \mathrm{HIV}$-infected patients. Clin Infect Dis. 2009;48(5):659-66. doi: $10.1086 / 597006$.

38. Tattevin P, Depatureaux AG, Chapplain JM, Dupont M, Souala F, Arvieux C, et al. Yellow fever vaccine is safe and effective in HIV-infected patients. AIDS. 2004; 18(5):825-7. PMID: 15075524.
39. Pistone $\mathrm{T}$, Verdière $\mathrm{CH}$, Receveur $\mathrm{MC}$, Ezzedine $\mathrm{K}$, Lafon ME, Malvy D. Immunogenicity and tolerability of yellow fever vaccination in 23 French HIV-infected patients. Curr HIV Res. 2010;8(6):461-6. doi: 10.2174/157016210793499277.

40. Barte H, Horvath TH, Rutherford GW. Yellow fever vaccine for patients with HIV infection. Cochrane Database Syst Rev. 2014;(1):CD010929. doi: 10.1002/14651858. CD010929.pub2.

41. Ho YL, Enohata T, Lopes MH, De Sousa Dos Santos S. Vaccination in Brazilian HIVinfected adults: a cross-sectional study. AIDS Patient Care STDS. 2008;22(1):65-70. doi: 10.1089/apc.2007.0059.

42. Kengsakul K, Sathirapongsasuti K, Punyagupta S. Fatal myeloencephalitis following yellow fever vaccination in a case with HIV infection. J Med Assoc Thai. 2002;(85):131-4. PMID: 12075714

43. Azevedo LS, Lasmar EP, Contieri FL, Boin I, Percegona L, Saber LT, et al. Yellow fever vaccination in organ transplanted patients: is it safe? A multicenter study. Transpl Infect Dis. 2012;14(3): 237-41. doi: 10.1111/j.1399-3062.2011. 00686.x.

44. Slifka MK, Hammarlund E, Lewis MW, Poore EA, Hanifin JM, Marr KA, et al. Antiviral immune response after live yellow fever vaccination of a kidney transplant recipient treated with IVIG. Transplantation. 2013;95(9):e59-61. doi: 10.1097/TP.0b013e 31828 c6d9e.

45. Gowda R, Cartwright K, Bremner JA, Green ST. Yellow fever vaccine: a successful vaccination of an immunocompromised patient. Eur J Haematol. 2004;72(4) 299-301. doi: 10.1111/j.1600-0609.2004. 00218.x.

46. Yax JA, Farnon EC, Cary Engleberg N. Successful immunization of an allogeneic bone marrow transplant recipient with live, attenuated yellow fever vaccine. J Travel Med. 2009;16(5):365-7. doi: 10.1111/ j.1708-8305.2009.00336.x

47. Avelino-Silva VI, Leal FE, Sabino EC, Nishiya AS, da Silva Freire M, Blumm F, et al. Yellow fever vaccine viremia following ablative BM suppression in AML. Bone Marrow Transplant. 2013;48(7):1008-9. doi: 10.1038/bmt.2012.277.

48. Farez MF, Correale J. Yellow fever vaccination and increased relapse rate in travelers with multiple sclerosis. Arch Neurol. 2011 68(10):1267-71. doi: 10.1001/archneurol. 2011.131

49. Rutkowski K, Ewan PW, Nasser SM. Administration of yellow fever vaccine in patients with egg allergy. Int Arch Allergy Immunol. 2013;161(3):274-8. doi: 10.1159/ 000346350.

50. Smith D, Wong P, Gomez R, White K. Ovalbumin content in the yellow fever vaccine. J Allergy Clin Immunol Pract. 2015;3(5):794-5. doi: 10.1016/j.jaip.2015. 03.011 .

51. Roukens AH, Vossen AC, van Dissel JT, Visser LG. Reduced intradermal test dose of yellow fever vaccine induces protective immunity in individuals with egg allergy. Vaccine. 2009;27(18):2408-9. doi: 10.1016/j. vaccine.2009.02.049. 
52. Martins RM, Maia Mde L, Farias RH, Camacho LA, Freire MS, Galler R, et al. 17DD yellow fever vaccine: a double blind, randomized clinical trial of immunogenicity and safety on a dose-response study. Hum Vaccin Immunother. 2013;9(4):879-88. doi: 10.4161/hv.22982.

53. Rabello A, Orsini M, Disch J, Marcial T, Leal Mda L, Freire Mda S, et al. Low frequency of side effects following an incidental 25 times concentrated dose of yellow fever vaccine. Rev Soc Bras Med Trop. 2002;35(2):177-80. doi: 10.1590/ S0037-86822002000200008.

54. Carneiro M, Lara Bda S, Schimidt B, Gais L. Superdosagem da vacina 17DD contra febre amarela, em uma regio do sul do
Brasil. Rev Soc Bras Med Trop. 2011; 44(2):252-3. doi: 10.1590/S0037-86822011 000200025.

55. Seligman SJ. Yellow fever virus vaccine-associated deaths in young women. Emerg Infect Dis. 2011;17(10):1891-3. doi: 10.3201/eid1710.101789.

56. Klein SL, Marriott I, Fish EN. Sex-based differences in immune function and responses to vaccination. Trans R Soc Trop Med Hyg. 2015;109(1):9-15. doi: 10.1093/ trstmh/tru167.

57. Pulendran B, Miller J, Querec TD, Akondy R, Moseley N, Laur O, et al. Case of yellow fever vaccine-associated viscerotropic disease with prolonged viremia, robust adaptiveimmune responses, and polymorphisms in CCR5 and RANTES genes. J Infect Dis. 2008;198(4):500-7. doi: 10.1086/590187.

58. Durbin AP, Setse R, Omer SB, Palmer JG, Spaeder JA, Baker J, et al. Monitoring adverse events following yellow fever vaccination using an integrated telephone and Internet-based system. Vaccine. 2009; 27(44):6143-7. doi: 10.1016/j.vaccine.2009. 08.024

Manuscript submitted 16 May 2017. Revised version accepted for publication on 11 August 2017.
RESUMEN

Vacuna antiamarílica y riesgo de eventos adversos graves: revisión sistemática
Objetivos. Evaluar las contraindicaciones y precauciones en relación con la vacuna antiamarílica en los grupos de riesgo.

Métodos. Se realizó una revisión bibliográfica mediante una búsqueda de los términos "yellow fever vaccine" [vacuna antiamarílica] y "adverse events" [eventos adversos] en PubMed; se encontraron 207 estudios, 43 de los cuales cumplían los criterios de inclusión para formar parte de la revisión sistemática.

Resultados. Los resultados de la primera dosis de la vacuna antiamarílica en adultos mayores fueron contradictorios: en algunos se observaron eventos adversos y en otros, beneficios. Por lo tanto, se recomienda precaución y que la decisión de suministrar la vacuna a este grupo se tome caso por caso. Las mismas precauciones se justifican en los lactantes de 6 a 8 meses; se considera contraindicada en los menores de 6 meses y segura en los mayores de 9 meses. La vacuna antiamarílica parece segura en el primer trimestre del embarazo y probablemente durante toda la gestación, pues no se asoció con un aumento de malformaciones. Durante la lactancia, su uso también es controvertido. Parece segura en personas con tratamiento inmunomodulador o inmunosupresor, personas con enfermedades inmunosupresoras y pacientes con trasplante de visceras macizas y células madre hematopoyéticas; sin embargo, en los trasplantes de células madre solo se debe aplicar una dosis de refuerzo una vez que se recupere la inmunidad. En los pacientes con infección por el VIH con un recuento de células CD4+ superior a 200 células $/ \mathrm{mm}^{3}$ no se produjo un aumento del riesgo de eventos adversos por la vacuna antiamarílica. Los protocolos de vacunación contra la alergia al huevo parecen proporcionar una forma segura de vacunar a estos pacientes.

Conclusiones. La seguridad de la vacuna antiamarílica se ha confirmado sobre la base de muchas campañas de vacunación y múltiples estudios. Los eventos adversos parecen ser más frecuentes después de la dosis inicial, principalmente en los grupos de riesgo. No obstante, en esta revisión se evaluó la vacuna antiamarílica en varios grupos de riesgo y se encontró que es segura en la mayoría de ellos.

Palabras clave
Fiebre amarilla; vacuna contra la fiebre amarilla; efectos colaterales y reacciones adversas relacionados con medicamentos; grupos de riesgo; revisión sistematica. 
RESUMO

\section{Vacina contra febre amarela e risco de eventos adversos graves: revisão sistemática}

Palavras-chave
Objetivos. Avaliar contraindicações e precauções para a vacina contra febre amarela em populações de risco.

Métodos. Foi conduzida uma revisão da literatura com uma busca na base de dados PubMed dos termos "vacina contra febre amarela" e "eventos adversos" (EAs). Foram encontrados 207 estudos, sendo que 43 satisfizeram os critérios de inclusão e foram incluídos na revisão sistemática.

Resultados. Os resultados para a primeira dose da vacina contra febre amarela em pacientes idosos foram conflitantes, alguns estudos demonstraram EAs enquanto outros demonstraram benefícios. Recomenda-se precaução e avalição caso a caso ao se decidir por vacinar este grupo da população. As mesmas precauções se justificam quanto à vacinação de bebês entre 6 e 8 meses de idade, sendo contraindicada antes dos 6 meses e segura após os 9 meses. A vacina parece ser segura para ser administrada no primeiro trimestre de gestação e provavelmente ao longo de toda a gestação, porque não se verificou associação com aumento da ocorrência de malformações congênitas. A vacinação de mulheres lactantes é ainda controversa. A vacina parece segura para ser administrada em indivíduos em uso de imunomoduladores ou imunossupressores, portadores de doenças imunossupressoras e pacientes submetidos a transplantes de células-tronco hematopoiéticas e de órgãos sólidos. No caso do transplante de células-tronco, a dose de reforço da vacina só deve ser aplicada após ser recuperada a imunidade. Pacientes infectados pelo HIV com contagem de CD4+ >200 células $/ \mathrm{mm}^{3}$ não têm um risco maior de EAs com a vacina. Seguir os protocolos de vacinação nos casos de alergia à proteína do ovo é uma forma segura de imunizar esses indivíduos. Conclusões. A segurança da vacina contra febre amarela foi confirmada a partir de dados obtidos em campanhas de vacinação e vários estudos. Parece que os EAs ocorrem com maior frequência com a vacinação pela primeira vez, principalmente nos grupos de risco. Porém, esta revisão analisou a vacina em vários grupos de risco e verificou ser segura para a maioria destes grupos.

Febre amarela; vacina contra febre amarela; efeitos colaterais e reações adversas relacionados a medicamentos; grupos de risco; revisão sistemática. 